\title{
Faktor Pendidikan, Status Perkawinan dan Jumlah Tanggungan serta Dampaknya pada Keaktifan Perempuan Mengikuti Kelompok Arisan (Survei Kelompok Arisan Ibu Rumah Tangga dan Profesi)
}

\author{
NOVITA \\ Dosen Tetap Sekolah Tinggi Ilmu Ekonomi Riau \\ Jln. HR. Subrantas 57 Panam Pekanbaru 28293 Telp. (0761) 63237 \\ E-mail : novitaq8@gmail.com
}

\begin{abstract}
Learning the problems faced by women in the concept of women empowerment makes it important to always get a solution. Women's arisan groups become one of the place of empowerment for women to grow and develop in order to increase prosperity and equality. The issue of women's activeness in arisan groups is one of the problems that causes less successful empowerment to be implemented. Through survey methods conducted on housewives and professional groups who joined as members in arisan groups in Pekanbaru City by using questionnaires distributed to 31 members of the arisan group taken proportionally and analyzed by using multiple regression analysis and assisted with the program WarpPLS. The result of the research shows that education factor, status and amenability factor give significant influence to women activity in arisan group (P-value: 0,02, 0,03 and 0,01). Educational and status factors have a negative influence on liveliness and amenability factors have a positive effect. $26 \%$ of women's activeness in the arisan group can be explained through education factor, status and amenability.
\end{abstract}

Keywords: Education, Marital Status, Amenability and Activity of Women

Pemberdayaan perempuan menjadi sebuah program nasional yang mendapatkan perhatian banyak kalangan. Perempuan menjadi sumber daya manusia yang perlu diberdayakan sehingga pencapaian kesejahteraan dapat dengan mudah diwujudkan.

Menurut Khotimah, K. (2009) partisipasi perempuan di pasar tenaga kerja mengalami peningkatan yang cukup nyata, meskipun prosentasenya kecil jika dibandingkan dengan laki-laki. Perubahan ini menunjukkan adanya peningkatan peran perempuan yang sangat berarti dalam kegiatan ekonomi di Indonesia. Namun demikian, struktur angkatan kerja perempuan memiliki tingkat pendidikan yang rendah. Dengan demikian, sebagian besar perempuan masih berkiprah di sektor informal atau pekerjaan yang tidak memerlukan kualitas pengetahuan dan keterampilan canggih atau spesifik. Dalam perspektif gender, proporsi tenaga kerja perempuan dan laki-laki di sektor informal adalah $40 \%$ perempuan, dan $60 \%$ laki-laki.
Proporsi tenaga kerja perempuan di sektor informal ini mencakup $70 \%$ dari keseluruhan tenaga kerja perempuan.

Hal tersebut menunjukkan bahwa perempuan memiliki andil dalam pembangunan ekonomi melalui sektor informal. Salah satu sektor informal dalam berkelompok para perempuan ini adalah kelompok arisan. Menurut Anggraeni, D. P. (2014) bahwa dalam bidang ekonomi, praktik arisan merupakan salah satu bentuk dari Rotating Savings and Credit Associations (ROSCA). Namun budaya arisan menjadi unik manakala berada pada konteks latar belakang sosiokultural dimana budaya tersebut tumbuh. Arisan Cantiq dan arisan Gold merupakan dua kelompok arisan yang terdapat di Surabaya yang anggotanya terdiri dari para perempuan kelas menengah urban. Praktik arisan dalam kedua kelompok tersebut pun mengalami modifikasi dan variasi karena motivasi ekonomi tidak lagi menjadi dominan. Arisan kemudian merupakan 
sebuah agensi bagi para anggota untuk mendapatkan rekognisi sosial dan budaya.

Namun berbagai persoalan muncul seperti yang disampaikan dalam penelitian Safitri, P. (2015) bahwa arisan khususnya pada perempuan dianggap mengalami modifikasi khususnya pada bentuk kegiatan, tujuan arisan dan pelaku arisan. Media massa mengkonstruksi arisan sebagai kegiatan yang dekat dengan pola gaya hidup glamour namun tetap memiliki sisi positif.

Selain itu juga masalah keaktifan perempuan dalam kelompok arisan ini juga menjadi tanda tanya, sebagian perempuan yang terdiri dari berbagai profesi mulai dari ibu rumah tangga, para kelompok profesi dalam lainnya memiliki kepentingan yang berbeda sehingga menyebabkan mereka kurang aktif dalam aktifitas kegiatan arisan yang mereka ikuti.

Menurut Khayati, E. (2007) bahwa faktor pendidikan adalah salah satu jalan menjadikan perempuan sebagai agen perubahan, bukan sekedar penerima pasif program-program pemberdayaan. Pendidikan juga dapat menjadi salah satu faktor yang memungkinkan perempuan memiliki independensi (kemandirian) ekonomi dengan bekerja baik di luar maupun di dalam rumah tinggalnya.

Menurut Gayatri, M. (2013) bahwa sektor pendidikan merupakan sektor yang penting dalam pembangunan karena sektor pendidikan merupakan salah satu sektor kunci untuk keberhasilan pembangunan terutama pembangunan sumberdaya manusia. Kondisi pendidikan yang semakin membaik merupakan kemajuan pembangunan bidang pendidikan. Keberhasilan pendidikan juga ditandai oleh aksesibilitas pendidikan berdasarkan gender, dengan melihat tingkat kesenjangan yang terjadi antara laki-laki dan perempuan dalam mengakses pendidikan.

$$
\text { Selain pendidikan, status }
$$

perkawinan juga ada kaitannya dengan peran aktif perempuan dalam kelompok arisan. Menurut Kurnianingtyas, R. (2009) bahwa terdapat perbedaan yang sangat signifikan pada tingkat penerimaan diri wanita bekerja usia dewasa dini antara status lajang, menikah, dan janda. Status menikah memiliki tingkat penerimaan diri yang tinggi, status janda memiliki tingkat penerimaan diri yang sedang, dan status lajang memiliki tingkat penerimaan diri yang rendah. Terdapat perbedaan yang signifikan pada penerimaan diri antara wanita berstatus menikah dengan janda, terdapat perbedaan yang sangat signifikan pada penerimaan diri antara wanita berstatus menikah dengan lajang, terdapat perbedaan yang signifikan pada penerimaan diri antara wanita berstatus janda dengan lajang.

Juga faktor tanggungan dalam keluarga memberikan kontribusi dalam sikap perempuan ikut aktif dalam kelompok arisan. Menurut Purwanti, E., \& Rohayati, E. (2015) bahwa terdapat pengaruh jumlah tanggungan keluarga terhadap partisipasi kerja tenaga kerja wanita yang signifikan, semakin tinggi jumlah tanggungan keluarga maka semakin tinggi pula partisipasi kerja tenaga kerja wanita pada industri kerupuk kedelai, jumlah tanggungan keluarga yang tinggi memerlukan biaya hidup yang tinggi pula sehingga akan meningkatkan partisipasi kerja agar pendapatan juga meningkat, terdapat pengaruh pendapatan terhadap partisipasi kerja tenaga kerja wanita yang signifikan, semakin tinggi pendapatan akan meningkatkan partisipasi kerja tenaga kerja wanita pada industri.

Berdasarkan uraian tersebut, maka penulis tertarik ingin membuktikan bahwa apakah keaktifan perempuan dalam kelompok arisan dipengaruhi oleh faktor pendidikan, status perkawinannya dan juga jumlah tanggungan dalam keluarga.

\section{METODE}

Jenis penelitian yang digunakan dalam penelitian ini adalah penelitian survey. Survey dilakukan pada kelompok perempuan ibu rumah tangga yang tersebar pada komplek perumahan dan juga pada kelompok perempuan profesi yang bekerja

$$
\text { p.ISSN: } 2407-800 X \quad \text { e.ISSN: } 2541-4356
$$


berdasarkan keahliannya. Sampel diambil sebanyak 31 orang dengan metode proporsional random sampling dan juga data yang berhasil dikumpulkan dianalisis dengan teknik analisis regresi berganda menggunakan program WarpPLS.

\section{HASIL}

Penelitian dilakukan selama 1 bulan dengan survey yang dilakukan kepada 31 orang anggota arisan baik yang pada komplek perumahan yakni ibu-ibu rumah tangga maupun dari kelompok professional yakni kelompok dosen perempuan. Data yang dikumpulkan dinilai kelayakannya dengan melakukan uji validitas dan uji reliabilitas serta dilakukan uji normalitas data sehingga dapat yang diperoleh bisa dianalisis dengan menggunakan analisis statistik parametric.

Berdasarkan hasil pengolahan data yang dilakukan dengan menggunakan program WarpPLS diperoleh hasil penelitian sebagai berikut:

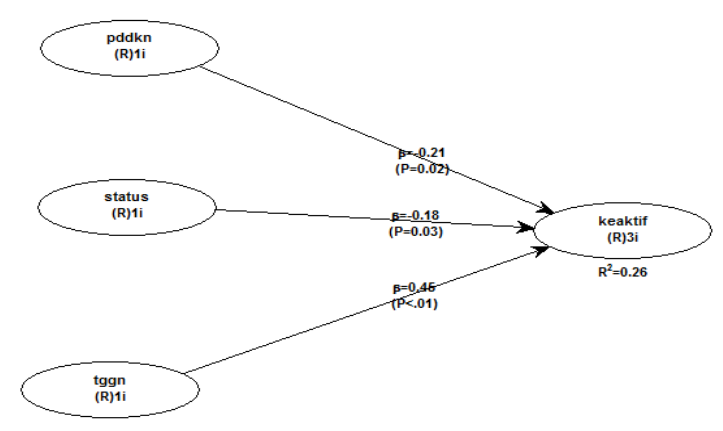

Gambar 1

Model temuan penelitian
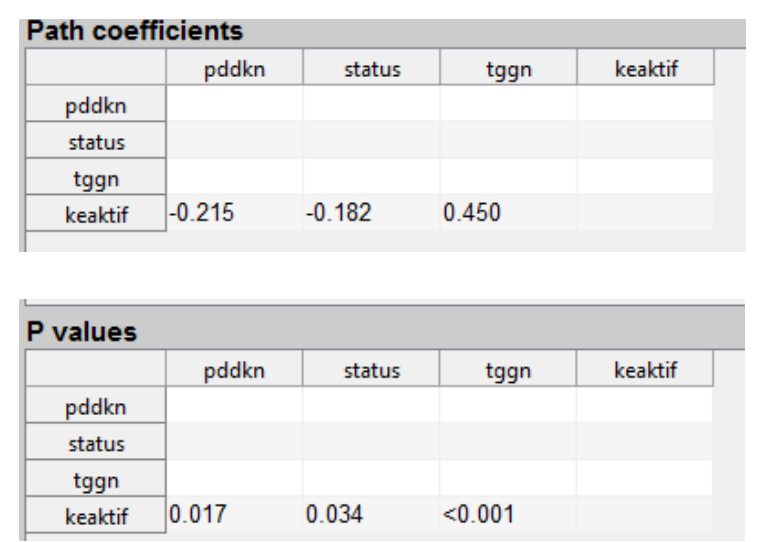

Dari model tersebut di atas, dapat diketahui bahwa dari variabel independen yakni pendidikan (pddkn), kemudian status perkawinan (status) dan jumlah tanggungan (tggn) serta variabel dependent adalah keaktifan perempuan dalam kelompok arisan (keaktif), maka diperoleh nilai koefisien dan $\mathrm{p}$ value sebagai berikut:

1. Pengaruh pendidikan perempuan terhadap keaktifan perempuan dalam kelompok arisan yakni sebesar -0.21 artinya adalah pendidikan perempuan memberikan pengaruh yang negative terhadap keaktifan perempuan dalam kelompok arisan. Kemudian dilihat dari nilai $\mathrm{p}$ valuenya adalah sebesar $0,021<0,05$ sehingga dapat dikatakan bahwa pengaruh pendidikan signifikan terhadap keaktifan perempuan dalam kelompok arisan.

2. Kemudian dapat dilihat pengaruh variabel status perkawinan dengan nilai yang diperoleh untuk koefisien regresinya sebesar $-0,18$ yang berarti bahwa status perkawinan memberikan pengaruh yang negative terhadap keaktifan perempuan dalam kelompok arisan. Nilai $p$ value sebesar $0,03>0,05$ sehingga dapat dikatakan bahwa pengaruh status perkawinan berpengaruh signifikan terhadap keaktifan perempuan mengikuti kelompok arisan.

3. Terakhir adalah pengaruh jumlah tanggungan memiliki nilai pengaruh positif $(0,46)$ dan nilai signifikansi untuk $\mathrm{p}$ value sebesar $0.01<0,05$ sehingga dapat dikatakan bahwa jumlah tanggungan berpengaruh signifikan terhadap keaktifan perempuan dalam kelompok arisan.

4. Selain itu juga dapat diketahui kontribusi dari variabel tingkat pendidikan, status perkawinan dan juga jumlah tanggungan terhadap keaktifan perempuan dalam kelompok arisan sebesar $26 \%$. 


\section{PEMBAHASAN}

Dari uraian hasil penelitian di atas, maka dapat dilakukan pembahasan satu demi satu sebagai berikut:

\section{Pendidikan tinggi menyebabkan perempuan kurang aktif dalam kelompok arisan.}

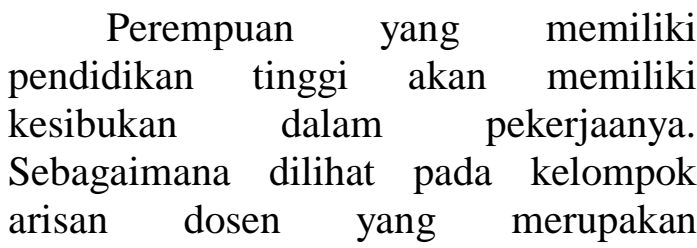
perwakilan dari perempuan yang berpendidikan tinggi, mereka akan lebih mengatur jadwal yang mereka miliki untuk berbagai aktifitas, sebagian dari perempuan yang berprofesi akan mengatur pertemuan seperti di rumah makan dan serba simple artinya sudah tersedia, ketemuan langsung membahas arisan dan makan-makan. Kemudian bila sudah selesai mereka akan mengatur acara lain seperti "koro-koro".

Sebaliknya bila perempuan yang berpendidikan rendah, mereka lebih aktif dalam kelompok arisan, mereka akan mudah diatur dan patuh pada ketua arisan. Selain itu juga mereka akan berusaha mencari penceramah yang dapat memberikan santapan rohani kepada mereka dalam rangka menambah wawasan dan pengetahuan yang berguna dalam kehidupan mereka berumah tangga.

Selain itu juga, mereka juga melakukan aktifitas-aktifitas produktif, seperti belajar ketrampilan dan juga menambah motivasi dengan berkunjung ke tempat-tempat produksi. Kegiatan ini selalu dilakukan dengan maksud untuk menambah wawasan dan pengetahuan yang sangat berguna bagi mereka dalam kehidupan berumah tangga.

Hasil penelitian ini menunjukkan bahwa bagi perempuan yang berpendidikan lebih tinggi akan sangat sempit jadwal yang mereka miliki, sehingga untuk urusan yang mereka anggap tidak penting, maka mereka akan abaikan dan sebagian dari mereka lebih menjadikan arisan sebagai tempat untuk bersenang-senang, ketemu dengan teman-teman mereka dalam berbagai kesempitan jadwal yang mereka atur.

Sebagaimana dijelaskan dalam hasil penelitian Asfiati, H. A. H. (2016) bahwa pengajian bulanan merupakan salah satu program yang menggali aktivitas keberagamaan dalam rangka meningkatkan pendidikan keberagamaan anggota Dharma Wanita.

Adapun kendala yang ditemukan yakni penyamaan persepsi tentang penentuan waktu dan jadwal kegiatan karena masing-masing anggota mempunyai kesibukan tersendiri yang juga mendukung aktivitas kegiatan lainnya sebagai istri Pegawai Negeri Sipil dan sebagai Pegawai Negeri Sipil. Kendala lainnya karena sifat heterogen antara pengurus dan anggota sehingga harus kerja keras dalam upaya peningkatan pendidikan keberagamaan.

Berdasarkan penjelasan tersebut menjelaskan bahwa melalui pendidikan keaktifan perempuan dalam kelompok menjadi kurang aktif. Kelemahannya adalah pada aktifitas yang padat perempuan dan pada kelompok perempuan profesi ini mereka pada dasarnya sudah berdaya sehingga meraka bukan lagi kelompok yang diberdayakan.

\section{Perempuan yang menikah kurang aktif dalam kelompok arisan.}

Status pernikahan seorang perempuan membuat mereka kurang aktif dalam kelompok ariasan, hal ini menunjukkan bahwa perempuan yang sibuk dengan urusan keluarganya yakni sudah menikah dan harus mengurus rumah tangga mereka dan juga berusaha menjaga keluarga dan mengurus suami menyebabkan kurang

p.ISSN: $2407-800 X \quad$ e.ISSN: $2541-4356$ 
waktu mereka dalam mengikuti kegiatan kelompok arisan.

Terkadang anggota kelompok seperti ini hanya mengikuti kelompok arisan dengan izin suami dan atau apabila pekerjaan utama mereka sudah selesai. Kondisi ini membuat mereka lebih aktif di rumah dibandingkan di luar rumah. Terkadang untuk sekedar bersilaturahmi ke tetangga sebelah rumah saja mereka tidak memiliki waktu yang memadai.

Perempuan yang belum berumah tangga atau janda memiliki waktu yang lebih banyak untuk berkumpul sesama mereka.

\section{Tanggungan keluarga membuat perempuan menjadi aktif dalam kelompok arisan.}

Jumlah tanggungan menyebab kan perempuan aktif dalam arisan, hal ini menunjukkan bahwa perempuan yang memiliki banyak akan akan membutuhkan banyak tabungan sehingga dengan mereka akan memanfaatkan arisan sebagai tempat menabung.

Selain itu juga, arisan juga dapat digunakan untuk antisipasi keuangan dalam rangka membuat ekonnomi keluarga semakin baik lagi. Menguatkan hasil penelitian ini dari hasil penelitian yang disampaikan oleh Kusumastuti, N. A., \& Purwanti, E. Y. (2012) bahwa variabel pendapatan dan jumlah tanggungan keluarga berpengaruh positif dan signifikan terhadap curahan jam kerja pedagang sayur wanita. Variabel umur dan pendapatan suami berpengaruh negatif dan tidak signifikan terhadap curahan jam kerja pedagang sayur wanita. variabel jarak tempuh ke tempat kerja berpengaruh positif tetapi tidak signifikan terhadap curahan jam kerja. Total pendapatan pedagang sayur wanita dapat dikontribusikan menjadi pendapatan keluarga. Kontribusi pendapatan pedagang sayur wanita yang dapat diberikan pada pendapatan rumah tangga cukup tinggi sebesar 44, 01 persen.

Uraian tersebut menjelaskan bahwa tanggungan keluarga akan mengurangi berbagai hal juga akan mengurangi kesempatan bagi perempuan dalam beraktifitas di luar rumah.

\section{SIMPULAN}

Berdasarkan uraian hasil penelitian dan pembahasan maka dapat ditarik kesimpulan bahwa pendidikan keaktifan perempuan dalam kelompok menjadi kurang aktif. Kelemahannya adalah pada aktifitas yang padat perempuan dan pada kelompok perempuan profesi ini mereka pada dasarnya sudah berdaya sehingga meraka bukan lagi kelompok yang diberdayakan.

Perempuan yang belum berumah tangga atau janda memiliki waktu yang lebih banyak untuk berkumpul sesama mereka. Kemudian perempuan yang banyak memiliki tanggungan akan semakin aktif dalam kelompok arisan.

\section{DAFTAR RUJUKAN}

Anggraeni, D. P. (2014). budaya arisan dalam perspektif bourdieu: studi kelompok arisan perempuan kelas menengah di surabaya (doctoral dissertation, universitas airlangga).

Asfiati, H. A. H. (2016). Peningkatan aktivitas pendidikan keberagamaan istri pegawai negeri sipil melalui arisan pada kegiatan rutinitas bulanan di dharma wanita persatuan iain padangsidimpuan. Tazkir: Jurnal Penelitian Ilmu-ilmu Sosial dan Keislaman, 2(2), 55-70.

Gayatri, M. (2013). Faktor dan dampak ketimpangan pendidikan perempuan dalam kehidupan perempuan. 
Khayati, E. (2007). Pendidikan dan Independensi Perempuan. Jurnal Ekonomi.

Khotimah, K. (2009). Diskriminasi gender terhadap perempuan dalam sektor pekerjaan. Yin Yang, 4(1), 158-180.

Kurnianingtyas, R. (2009). Penerimaan diri pada wanita bekerja usia dewasa dini ditinjau dari status pernikahan (Doctoral dissertation, Universitas Muhammadiyah Surakarta).

Kusumastuti, N. A., \& Purwanti, E. Y. (2012). Pengaruh faktor pendapatan, umur, jumlah tanggungan keluarga, pendapatan suami dan jarak tempuh ke tempat kerja terhadap curahan jam kerja pedagang sayur wanita (studi kasus di Pasar Umum Purwodadi) (Doctoral dissertation, Fakultas Ekonomika dan Bisnis).
Purwanti, E., \& Rohayati, E. (2015). Pengaruh Jumlah Tanggungan Keluarga, Pendapatan Terhadap Partisipasi Kerja Tenaga Kerja Wanita Pada Industri Kerupuk Kedelai Di Tuntang, Kab Semarang. Jurnal Ilmiah Among Makarti, 7(13).

Safitri, P. (2015). Representasi Arisan Sebagai Gaya Hidup Pada Perempuan Kelas Menengah di Indonesia yang Digambarkan Dalam Majalah Pesona dan Tabloid Nova (Doctoral dissertation, Universitas Airlangga). 